Open Journal of Gastroenterology and Hepatology
(ISSN:2637-4986)

\title{
Significance of nutritional treatment for patients with inflammatory bowel disease in the era of biologics
}

\section{Yoshihiro Yokoyama, Tomoya lida, Hiroshi Nakase}

Department of Gastroenterology and Hepatology, Sapporo Medical University, School of Medicine, Minami 1-jo Nishi 17-chome, Chuo-ku, Sapporo, Hokkaido, 060-8556, Japan, Phone: +81-11-6112111 Fax: +81-11-611-2282

\section{ABSTRACT}

Inflammatory bowel disease (IBD), including ulcerative colitis and Crohn's disease (CD), is a chronic gastrointestinal tract inflammatory disorder. Although its etiology remains unknown, it has been reported that nutrition is involved in the onset of IBD. Patients with IBD often experience malnutrition due to malabsorption and increased energy requirements. Malnutrition is a serious issue for patients with IBD, especially in young people. Growth retardation characterized by delayed skeletal maturation and onset of puberty is a representative complication. In addition, immunosuppression, osteoporosis, and sarcopenia are important issues. Functional foods and diets have been known to alleviate gastrointestinal inflammation by modulating inflammatory cytokines. Furthermore, appropriate nutritional treatment has been reported to be effective on the induction and maintenance of remission in patients with IBD, especially with $C D$. Conversely, there are negative reports regarding the efficacy of nutritional therapy in patients with IBD. Recently, various new therapeutic agents such as biologics have emerged as key drugs in IBD treatment. In this new era, the efficacy of nutritional treatment, including combination therapy with biologics, should be reconsidered to improve the quality of life in patients with IBD. In this review, the nutritional treatment for patients with IBD is reviewed, and the latest evidence is provided.

Supported by Health and Labour Sciences Research Grants for research on intractable diseases from the Ministry of Health, Labour and Welfare of Japan (Investigation and Research for intractable Inflammatory Bowel Disease), and Japan Society for the Promotion of Science (JSPS) Grants-in-Aid for Scientific Research (KAKENHI) Grant Number JP17J02428 (to T.I.) and JP18H02799 (to H.N.). The funders of the study had no role in the study design, data collection, data analysis, data interpretation, or writing of the report.

Keywords: Inflammatory bowel disease; ulcerative colitis; Crohn's disease; nutrition; biologics

*Correspondence to Author:

Hiroshi Nakase, MD, PhD

Department of Gastroenterology and Hepatology, Sapporo Medical University, School of Medicine, Minami 1-jo Nishi 17-chome, Chuoku, Sapporo, Hokkaido, 060-8556, Japan.

How to cite this article:

Yoshihiro Yokoyama, Tomoya lida, Hiroshi Nakase.Significance of nutritional treatment for patients with inflammatory bowel disease in the era of biologics.Open Journal of Gastroenterology and Hepatology, 2019, 2:20

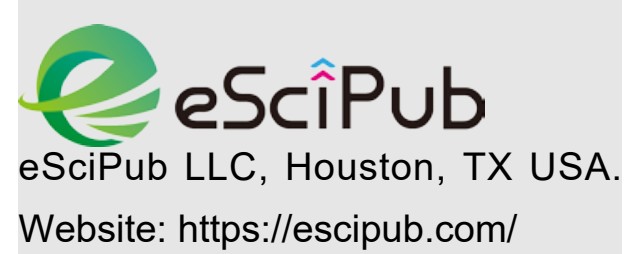




\section{INTRODUCTION}

Inflammatory bowel disease (IBD) is a disorder characterized by chronic gastrointestinal inflammation and mainly divided Crohn's disease (CD) and ulcerative colitis (UC). Its etiology remains unknown; however, genetic, environmental, and microbial factors are believed to be relevant to complex immune responses $^{[1,2]}$.

IBD is not curable and recently occurs more commonly at a young age. Several complications, such as delayed skeletal maturation and onset of puberty, occur in association with chronic inflammation ${ }^{[3]}$. Moreover, they often need surgery because of intestinal stenosis, perforation, and invalid medical treatment that impaired their quality of life. Thus, patients with IBD need appropriate treatment to prevent such complications. The 5aminosalicylic acid (5-ASA) and steroids were classically used, but it has dramatically changed due to the advent of biological agents, which have continued the remission and have reduced the rate of surgical treatment ${ }^{[4]}$.

Along with the increasing use of biological agents, nutritional treatment also changes the position of patients with IBD although it remains a safe, an effective, and an important clinical management for patients with $\mid B D^{[5]}$, especially in children who require normal development.

The incidence of IBD has been increasing continuously worldwide, especially in Western and Asian countries ${ }^{[6,7]}$. Therefore, it is important to understand the effectiveness of nutritional treatment for IBD and to seek clinical help. The present review focuses on the significance of nutritional treatment for patients with IBD in the era of biologics.

\section{Pathogenesis of IBD}

The definite cause of IBD remains to be determined. Its pathogenesis is thought to involve genetic predisposition ${ }^{[8]}$, environmental factors such as sanitary condition or food changes, and host immune response to food antigens and microbiota. Recently, the relationship between host immunity and microbiota has been progressing dramatically due to the improvement of intestinal immunology and bacteriology. Intestinal bacteria is in harmony with the host, to exert various effects, such as the production and digestion of foods and nutrients. Aside from environmental factors such as drugs, smoking, and infection, several factors have been found to influence the composition of the intestinal flora ${ }^{[9]}$. Diet affects the composition of the gut microbiota and serves as a substrate for microbial synthesis of metabolites ${ }^{[10]}$, which contribute to the change of the mucosal immune system. For example, dietary protein, particularly from meat, may increase the release of marked quantities of branched chain fatty acids and compounds such as ammonia, phenols, and nitric oxide, in addition to sulfide compounds that may have toxic effects on the mucosal epithelium ${ }^{[11]}$. Dietary fat from meat such as $n-6$ polyunsaturated fatty acid (PUFA) may increase the release of arachidonic acid that may be incorporated in the cell membrane and metabolized to pro- and anti-inflammatory 
eicosanoids ${ }^{[12]}$. Specific amino acids, such as glutamine and arginine, are thought to be immunomodulatory and might be involved in mediating responses to metabolic stress, such as in inflamed intestines ${ }^{[13]}$. Other nutrients, such as vitamin $D$ and fiber, are thought to be involved in the pathogenesis of IBD ${ }^{[14,15]}$. The gut microbiota is involved greatly in T-cell differentiation ${ }^{[16]}$, and while intestinal mucosa is exposed constantly to intestinal bacteria and dietary antigens, intestinal tract macrophages contribute to the maintenance of homeostasis ${ }^{[17-}$ 19]. Dysbiosis changes the microbial function, by decreasing the metabolism of butyric acid, butanoate, and propanoate and increasing the oxidative stress, toxin secretion, amino acid, and sulfate transport ${ }^{[20-22]}$ (Figure 1).

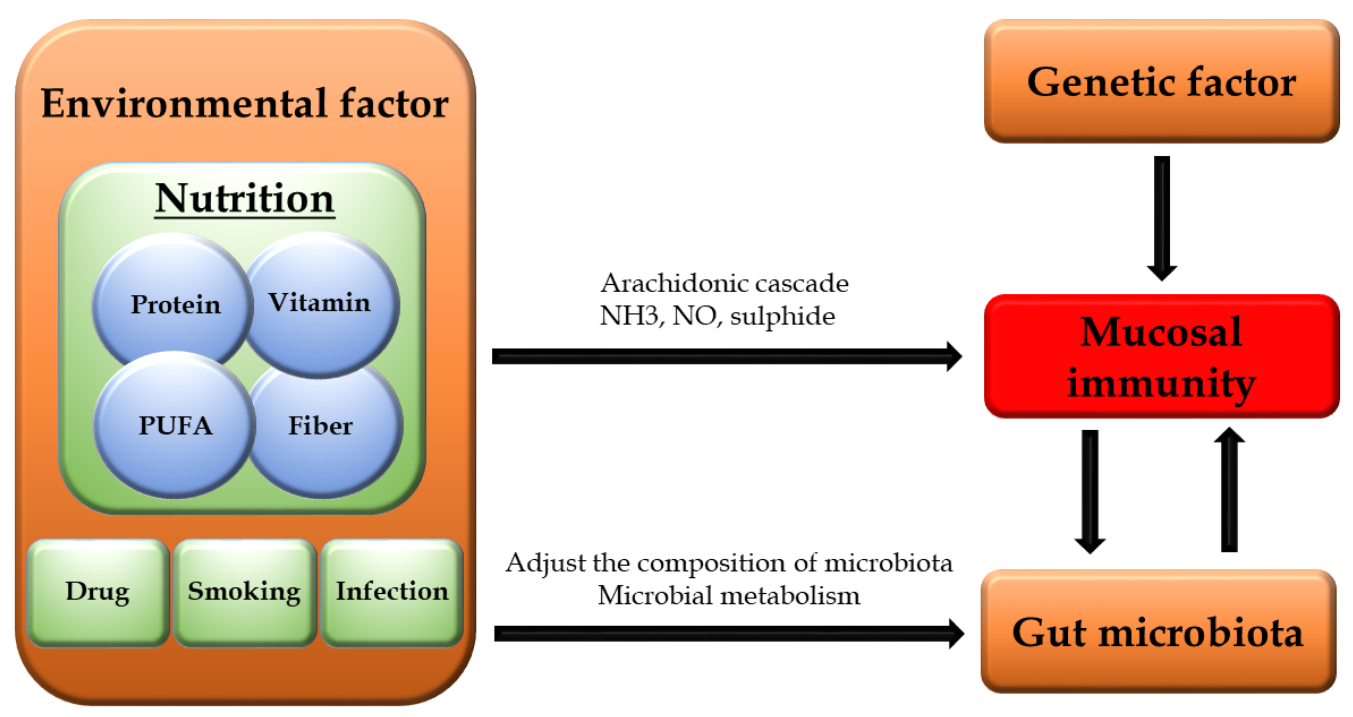

Figure 1 Relationship between IBD pathology and nutrition. Environmental factors, including nutrition, genetic factor, and gut microbiota are greatly involved in the onset of IBD. PUFA: polyunsaturated fatty acid, NO: nitric oxide

\section{Nutritional issue in IBD}

Malnutrition is common especially in pediatric patients with IBD. Clinical symptoms such as abdominal pain, diarrhea, and fever reduce the dietary intake, and catabolism is accelerated. Additionally, it causes protein leakage from digestive and absorption disorders such as lipids and trace elements and from erosions and ulcers during the active phase. Altered energy and nutritional requirements, malabsorption, and increased gastrointestinal losses are additional factors $^{[23]}$.

(1) Growth failure

Delayed puberty and growth failure are additional features that complicate the clinical management further in pediatric patients with IBD. Approximately one-third of children with CD have growth retardation at diagnosis ${ }^{[3]}$. Cytokines produced by chronic inflammation reduce the sensitivity of growth hormone, thereby suppressing the IGF-1 expression and further reducing the function of bone cells. 
Growth failure is greater due to worsened $C D$ than due to steroid use ${ }^{[24]}$. Suboptimal nutritional intake is the main determinant of undernutrition, although activation of the immune system and secretion of proinflammatory cytokines exert additional independent effects.

\section{(2) Anemia}

Anemia is a common manifestation of patients with IBD. Iron deficiency anemia primarily occurred due to gastrointestinal tract bleeding and iron malabsorption, followed by anemia due to chronic diseases ${ }^{[25]}$. In a population-based cohort study, the incidence rate of anemia was 19.3 per 100 person-years with the prevalence of $28.7 \%$ in $\mathrm{CD}$, compared with $12.9 \%$ and $16.5 \%$ for UC. In CD, anemia was associated with both increased risk and worse outcomes ${ }^{[26]}$. Regarding the treatment of anemia, the effectiveness of iron supplementation has been confirmed. According to a systematic review, intravenous iron supplementation is considered effective when rapid correction of anemia occurred, and if it is mild anemia, oral intake is considered adequate ${ }^{[27]}$. Vitamin B12 and folate deficiency are caused by malabsorption and deficiencies in vitamin B12 and folate that can lead to macrocytic anemia ${ }^{[28]}$.

\section{(3) Osteopenia}

Bone loss and osteopenia have been found, which are potentially caused by malnutrition, poor calcium intake or absorption, and use of corticosteroids $^{[29]}$. The prevalence of osteoporosis in pediatric patients with IBD is approximately the same as in adult patients and already present before steroid treatment ${ }^{[30]}$. A small number of studies list $C D$ (rather than UC) and vitamin $\mathrm{D}$ deficiency as risk factors of osteopenia and osteoporosis ${ }^{[31]}$. Male sex and low BMI were associated with increased risk for metabolic bone disease in IBD [32].

\section{(4) Sarcopenia}

Approximately half of the patients with IBD are sarcopenic, who are mostly normal or overweight and would not be identified as malnourished by traditional measures ${ }^{[33,34]}$.
Sarcopenia is a predictor of surgery ${ }^{[3,35,36]}$ and is also a predictor of osteopenia in patients with $\mid \mathrm{IBD}^{[37]}$. A retrospective cohort study has suggested that low muscle mass at the induction of an anti-TNF agent is a risk factor for treatment failure ${ }^{[38]}$.

(5) Vitamin and mineral deficiency

Fat-soluble vitamins such as vitamins $A$ and $D$ play protective roles against the pathogenesis of IBD. Accumulating evidence suggests that patients with IBD are frequently diagnosed with low levels of fat-soluble vitamins, and, therefore, specific supplementation of these vitamins are often recommended ${ }^{[39]}$. Patients with IBD require vitamin $D$ because it is involved in antiinflammatory pathways. Vitamin D promotes epithelial cell resistance to injury and suppresses inflammatory response to luminal antigens. Ananthakrishnan et al. ${ }^{[40]}$ showed that predicted levels of prediagnosis plasma $25(\mathrm{OH})$ $\mathrm{D}$ are associated with significant reduction in the risk of developing $C D$ and not significant reduction in the risk of UC. Garg et al. ${ }^{[41]}$ revealed that vitamin $D$ supplementation was associated with reduced intestinal inflammation in patients with active UC. Additionally, they reported that oral vitamin $D$ intake improved symptom-based activity scores. Continuous diarrhea decreases serum magnesium and potassium levels. Magnesium deficiency complicates electrolyte abnormalities such as hypocalcemia, hypophosphatemia, and hypokalemia. Oral supplementation is necessary while measuring blood concentration. Furthermore, zinc deficiency occurs due to diarrhea. Approximately $15 \%$ of patients with IBD have zinc deficiency ${ }^{[42]}$, characterized by 
facial rashes, glossitis, hair loss and delayed wound healing. Zinc deficiency may be diagnosed as a result of taste disorder. Recent studies suggest that zinc deficiency is a risk factor for hospitalization, surgery, and complications in patients with IBD ${ }^{\text {[43] }}$.

\section{Nutritional treatment in IBD}

(1) Enteral nutrition

Nutritional treatment was gradually accepted as internal medicine treatment for CD since the total parenteral nutrition (TPN) was reported in 1973 and elemental diet (ED) in 1980. The European pediatric $C D$ treatment guideline also recommends complete EN therapy as the first choice of induction therapy for patients with active $C D^{[44]}$. ED could involve reductions in luminal antigens and food exclusion, direct antiinflammatory effects of the formula, improved nutrition, or changes to the gut microbiota ${ }^{[45,46]}$. Multiple clinical trials for EN have been reported (Table 1), particularly in the induction treatment for $C D^{[47-67]}$. Comparative studies of $E N$ with steroids and polymeric diets have been conducted from 1980 to 1990 , and it has been reported that it has the same effect as steroids, especially in induction therapy for children. Several reports have also been made on CD maintenance therapy ${ }^{[68-77]}$. Takagi et al. ${ }^{[70]}$ showed that half of ED cases had sufficient effects in a randomized controlled trial (RCT). They randomly assigned 51 patients with CD remission who received 900 to $1,200 \mathrm{kcal}$ in ED and the control group freely eat meals, and the cumulative relapse rate was also examined. Then, during the average observation period of 11.9 months, the relapse rate of the half ED group was $34.6 \%$ only, whereas the control group was significantly higher at $64.0 \%$, and by performing half ED, the hazard ratio of $C D$ relapse was suppressed to 0.40 . Esaki et al. ${ }^{[69]}$ reported that 98 patients with $C D$ remission receiving nutritional therapy for more than 1,200 kcal days had a significantly lower cumulative relapse rate than 47 patients receiving $<1,200$ kcal days. Not only ED but also fat digestive and semi-digestive nutrition have been confirmed to be comparable to ED, and the nutritional choices also expanded. There is also some report on the effectiveness of EN for perioperative period ${ }^{[78-81]}$, and it has been suggested to reduce postoperative complications and reoperation

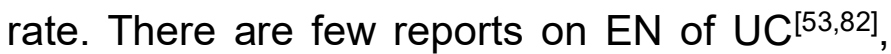
only comparison with TPN and Case series study, but both are only valid and have not been established as evidence. Meanwhile, the basic therapeutic agent for IBD is salazopyrin and steroids ${ }^{[83-85]}$, and drug therapy is evolving further. In addition, infliximab (IFX), an antiTNFa preparation, was formulated in $1993^{[86]}$, followed by adalimumab and golimumab ${ }^{[87,88]}$. Recently, many other biological products with other mechanisms of action have been developed ${ }^{[89-91]}$, and treatment options are expanding.

In this biologics era, the position of EN therapy has also changed. Recently, the combination use of anti-TNFa agents and EN therapy has been studied ${ }^{[92-100]}$ (Table 2). Hirai et al. ${ }^{[96]}$ reported that EN combination group had better cumulative remission maintenance rate than IFX alone group in their retrospective analysis of 
patients with CD who received remission and maintaining clinical remission among maintenance IFX therapy. Kamata et al. ${ }^{[97]}$ patients with CD than infliximab alone in a metareported that IFX effects on the reduction rate analysis. Recently, it has also been reported with were low in the EN therapy combination group. respect to efficacy of EN against loss of Nguyen et al. ${ }^{[98]}$ demonstrate that a combination response to anti-TNFa agents ${ }^{[95,99,100]}$. of infliximab and EN is more effective at inducing

\section{Table 1 Clinical trials on enternal nutrition}

\begin{tabular}{|c|c|c|c|c|c|c|}
\hline Author/Reference & Year & Patient & Study method & Study design & Endopoint & Outcome \\
\hline \multicolumn{7}{|l|}{ Induction for CD } \\
\hline Harries [47] & 1983 & CD & Prospective & EN vs. ordinary diet & Disease activity, nutritional status & Effective \\
\hline O'Morain et al [48] & 1984 & $\begin{array}{l}\text { Mild-Moderate } \\
\text { CD }\end{array}$ & RCT & EN vs. steroids & Simple activity index at 4 and 12 weeks & Effective \\
\hline Giaffer et al [49] & 1990 & Moderate CD & $\mathrm{RCT}$ & EN vs. polymeric diet & Clinical remission rate at 10 and 28 days & Effective \\
\hline Lochs et al [50] & 1991 & $\begin{array}{l}\text { Mild-Moderate } \\
\text { CD }\end{array}$ & Prospective & $\begin{array}{l}\text { EN vs. combination of } 6 \text { - } \\
\text { methylpredonisolone and } \\
\text { sulfasalazine }\end{array}$ & CDAl at 6 weeks & Not effective \\
\hline Rigaud et al [51] & 1991 & $\begin{array}{l}\text { Mild-Moderate } \\
\text { CD }\end{array}$ & RCT & EN vs. polymeric diet & CDAI at 14,21 and 28 days & Effective \\
\hline Lindor et al [52] & 1992 & CD & $\mathrm{RCT}$ & $\begin{array}{l}\text { EN vs. Steroids vs. } \\
\text { EN+Steroids }\end{array}$ & Remission rate at 1 month & Not effective \\
\hline $\begin{array}{l}\text { Gonzales-Huix et al } \\
\text { [53] }\end{array}$ & 1993 & $\begin{array}{l}\text { Moderate-Severe } \\
\text { UC }\end{array}$ & $\mathrm{RCT}$ & EN vs. TPN & $\begin{array}{l}\text { Remission rate, surgical rate, and } \\
\text { adverse effects }\end{array}$ & Effective \\
\hline Gorard et al [54] & 1993 & $\begin{array}{l}\text { Mild-Moderate } \\
\text { CD }\end{array}$ & Prospective & EN vs. steroids & CDAl and laboratory data at 4 weeks & Effective \\
\hline Fernandes et al [55] & 1995 & CD & Meta-analysis & $\begin{array}{l}\text { EN vs. steroids or } \\
\text { nonelemental diets }\end{array}$ & Clinical remission rate & Not effective \\
\hline Griffiths et al [56] & 1995 & CD & Meta-analysis & $\begin{array}{l}\text { EN vs. steroids or } \\
\text { nonelemental diets }\end{array}$ & Clinical remission rate & Not effective \\
\hline Zoli et al [57] & 1997 & Moderate CD & $\mathrm{RCT}$ & EN vs. steroids & Simple activity index at 2 weeks & Effective \\
\hline Heuschkel et al [58] & 2000 & Child CD & $\begin{array}{l}\text { Systematic } \\
\text { review }\end{array}$ & EN vs. steroids & Remission rate & Effective \\
\hline Verma et al [59] & 2000 & $\begin{array}{l}\text { Mild-Moderate } \\
\text { CD }\end{array}$ & $\mathrm{RCT}$ & EN vs. polymeric diet & CDAI & Effective \\
\hline Ludvigsson et al [60] & 2004 & Child CD & $\mathrm{RCT}$ & EN vs. polymeric diet & PCDAl at 6 weeks & Effective \\
\hline Grover et al [61] & 2014 & Child CD & Prospective & EN vs. not EN & $\begin{array}{l}\text { Clinical, biochemical, mucosal and transmural } \\
\text { remission rate }\end{array}$ & Effective \\
\hline $\begin{array}{l}\text { Sigall-Boneh et al } \\
\text { [62] }\end{array}$ & 2014 & $\begin{array}{l}\text { Mild-moderate } \\
\text { Child }\end{array}$ & Prospective & partial EN vs. not EN & Remission rate at 6 weeks & Effective \\
\hline
\end{tabular}


and young adult

CD

\begin{tabular}{|c|c|c|c|c|c|c|}
\hline Swaminath et al [63] & 2017 & Pediatric CD & $\begin{array}{l}\text { Systematic } \\
\text { review }\end{array}$ & EN vs. Steroids & Remission rate & Effective \\
\hline Yang et al [64] & 2017 & $\begin{array}{l}\text { CD with } \\
\text { complications }\end{array}$ & Prospective & EN vs. not EN & CDAl at 12 weeks & Effective \\
\hline Luo et al [65] & 2017 & Pediatric CD & Prospective & EN vs. IFX & PCDAl at 8 weeks & Effective \\
\hline Connors et al [66] & 2017 & Pediatric CD & Retrospective & EN vs. Steroids & $\begin{array}{l}\text { PDAI during } 4-12 \text { weeks, avoidance of } \\
\text { steroids over } 6 \text { years }\end{array}$ & Effective \\
\hline Narula et al [67] & 2018 & CD & $\begin{array}{l}\text { Systematic } \\
\text { review }\end{array}$ & EN vs. not EN & Clinical remission & Effective \\
\hline Maintenance for CD & & & & & & \\
\hline Wilschanski et al [68] & 1996 & Child CD & Retrospective & EN vs. not EN & Time to relapse and linear growth & Effective \\
\hline Esaki et al [69] & 2006 & Remission CD & Retrospective & EN vs. not EN & Recurrence rate & Effective \\
\hline Takagi et al [70] & 2006 & Remission CD & RCT & Half EN vs. not EN & Relapse rate over the 2-year period & Effective \\
\hline Yamamoto et al [71] & 2010 & Remission CD & $\begin{array}{l}\text { Systematic } \\
\text { review }\end{array}$ & EN vs. not EN & Clinical or endoscopic relapse & Effective \\
\hline Hanai et al [72] & 2012 & Remission CD & Prospective & EN vs. 6-mercaptopurine & Relapse rate $(C D A \geqq 200)$ for 2 years & Effective \\
\hline Duncan et al [73] & 2014 & $\begin{array}{l}\text { Remission, } \\
\text { pediatric CD }\end{array}$ & Retrospective & EN vs. not EN & Remission rate at 1 year & Effective \\
\hline Grover et al [74] & 2015 & Pediatric CD & Retrospective & $\begin{array}{l}\text { EN vs. Steroids in } \\
\text { thiopurine }\end{array}$ & $\begin{array}{l}\text { Steroid dependency, need for IFX, linear } \\
\text { growth, surgical resection over } 2 \text { years }\end{array}$ & Effective \\
\hline Kang et al [75] & 2015 & $\begin{array}{l}\text { Severe pediatric } \\
\text { CD }\end{array}$ & Prospective & $\begin{array}{l}\text { short-term partial EN vs. } \\
\text { not EN }\end{array}$ & Nutritional status and CDAI at 1 year & Effective \\
\hline El-Matary et al [76] & 2017 & Remission CD & $\begin{array}{l}\text { Systematic } \\
\text { review }\end{array}$ & EN vs. not EN & Relapse rate & Effective \\
\hline Akobeng et al [77] & 2018 & $\mathrm{CD}$ & $\begin{array}{l}\text { Systematic } \\
\text { review }\end{array}$ & EN vs. not EN & Clinical or endoscopic relapse & Not effective \\
\hline \multicolumn{7}{|c|}{ Perioperative period for CD } \\
\hline Ikeuchi et al [78] & 2004 & Postoperative CD & Retrospective & EN vs. not EN & Reoperation rate & Effective \\
\hline Yamamoto et al [79] & 2007 & Postoperative CD & Prospective & EN vs. not EN & $\begin{array}{l}\text { Endoscopic recurrence at } \\
6 \text { and } 12 \text { months }\end{array}$ & Effective \\
\hline Wang et al [80] & 2016 & Preoperative CD & Prospective & EN vs. not EN & Postoperative complication & Effective \\
\hline Brennan et al [81] & 2018 & Preoperative CD & Meta-analysis & EN vs. TPN & Postoperative complication & Effective \\
\hline \multicolumn{7}{|l|}{ Induction for UC } \\
\hline $\begin{array}{l}\text { Gonzales-Huix et al } \\
\text { [82] }\end{array}$ & 1993 & $\begin{array}{l}\text { Moderate-Severe } \\
\text { UC }\end{array}$ & $\mathrm{RCT}$ & EN vs. TPN & $\begin{array}{l}\text { Remission rate, Surgical rate, } \\
\text { Adverse effects }\end{array}$ & Effective \\
\hline Klaassen et al [83] & 1998 & Severe UC & Prospective & EN case series study & Tolerance, laboratory data & Effective \\
\hline
\end{tabular}

CD: Crohn's disease, EN: enteral nutrition, RCT: randomized controlled trial, CDAl: Crohn's disease activity index, UC: ulcerative colitis, TPN: total parenteral nutrition, PCDAl: pediatric Crohn's disease activity index, IFX: infliximab 
Table 2 Clinical trials on enternal nutrition combined with anti-TNFa agents

\begin{tabular}{|c|c|c|c|c|c|c|}
\hline Author/Reference & Year & Patient & Study method & Study design & Endopoint & Outcome \\
\hline Matsumoto et al [93] & 2005 & $C D$ & Retrospective & $\mathrm{IFX}+\mathrm{EN}$ vs. IFX+ TPN vs. IFX & CDAl at 2 weeks & Not effective \\
\hline Yamamoto et al [95] & 2010 & $C D$ & Prospective & $\mathrm{IFX}+\mathrm{EN}$ vs. IFX & Clinical remission rate $(\mathrm{CDAI}<150)$ & Not effective \\
\hline Sazuka et al [96] & 2012 & $C D$ & Retrospective & $\mathrm{IFX}+\mathrm{EN}$ vs. IFX & Rate of LOR & Effective \\
\hline Hirai et al [97] & 2013 & $C D$ & Retrospective & $\mathrm{IFX}+\mathrm{EN}$ vs. IFX & Remission rate $(\mathrm{CRP}<0.3 \mathrm{mg} / \mathrm{dl})$ & Effective \\
\hline Kamata et al [98] & 2015 & $C D$ & Retrospectve & IFX + EN vs. IFX & Sustaining IFX maintenance therapy & Effective \\
\hline Nguyen et al [99] & 2015 & $C D$ & Meta-analysis & $\mathrm{IFX}+\mathrm{EN}$ vs. IFX & Inducing and maintaining clinical remission & Effective \\
\hline Sugita et al [100] & 2018 & $\mathrm{CD}$ & Prospective & $A D A+E N$ vs. ADA & Non-ADA-LOR rate & Effective \\
\hline
\end{tabular}

CD: Crohn's disease, IFX: infliximab, EN: enteral nutrition, TPN: total parenteral nutrition, ADA: adalimumab, CDAl: Crohn's disease activity index, HBI: HarveyBradshaw Index, LOR: loss of response

(2) Parenteral nutrition

Since dietary antigens may be important stimulants for the mucosal immune system, bowel rest with TPN has been considered as a therapeutic option for patients with IBD. In malnutrition cases, TPN is selected first in a patient with frequent diarrhea, extensive small intestinal lesions, severe stenosis of the intestinal tract, slimming or abscess, and when massive bleeding occurs. Given the complications due to central venous puncture and subsequent management complications, EN therapy should be transferred as soon as possible. TPN as a primary therapy aimed to achieve bowel rest, to correct nutritional deficits, and to remove antigenic mucosal stimuli[101]. Various studies have analyzed the effects of TPN, which was used to treat patients with moderate-to-severe $C D$ especially in the 1980s ${ }^{[102-106]}$ (Table 3). Muller et al. ${ }^{[103]}$ prospectively evaluated the effects of TPN in 30 patients with CD, whereby $83 \%$ achieved remission, but relapse was common. Surgery could be avoided in 25 of 30 patients with complicated CD on 3 weeks of inpatient TPN, followed by 9 more weeks at home. Ostro et al. ${ }^{[104]}$ evaluated the effects of TPN in 100 patients with $C D$ refractory to conventional medical management. In their study, 90 patients received complete nutrient replacement and 10 received protein-sparing therapy and 77 achieved clinical remission. Greenberg et al. ${ }^{[106]}$ compared the effects of TPN, partial parenteral nutrition (PPN) with supplementary nutrition with a defined formula via NG tube, or PPN with supplementary normal diet. No significant differences were observed in the remission rates of $71 \%$ in the TPN group, $58 \%$ in the PPN with defined formula diet group, and $60 \%$ in the group with PPN and normal diet. Additionally, TPN was shown to play a role in the postoperative healing of enterocutaneous fistulas arising from surgical anastomosis or complicated fistulas in patients with $C D^{[107]}$. When comparing TPN and EN, TPN 
is associated with higher costs and significant There are two short-term studies about TPN with risks such as infection and should be restricted severe acute UC, but the results were no to patients who cannot take adequate nutrition $\operatorname{effect}^{[102,105]}$. enterally ${ }^{[108,109]}$.

\section{Table 3 Clinical trials on total parental nutrition}

\begin{tabular}{lllllll}
\hline Author/Reference & Year & Patient & Study method & Study design & Endopoint & Outcome \\
\hline Dickinson et al [103] & 1980 & UC and CD & Prospective & TPN vs. not TPN & Surgical rate and response rate & Not effective \\
Muller et al [104] & 1983 & CD & Prospective & TPN case series study & Recurrence rate & Not effective \\
Ostro et al [105] & 1985 & CD & Retrospective & TPN vs. not TPN & Remission rate & Effective \\
Mclntyre et al [106] & 1986 & UC and CD & RCT & TPN vs. not TPN & Operation rate, mortality rate, & Effective \\
Greenberg et al [107] & 1988 & CD & RCT & TPN vs. EN vs. PPN & Remission rate & (only surgical rate in CD) \\
\hline
\end{tabular}

UC: ulcerative colitis, CD: Crohn's disease, RCT: randomized controlled trial, TPN: total parenteral nutrition, EN: enteral nutrition, PPN: partial parenteral nutrition

\section{Dietary treatment}

As a basis of dietary treatment in IBD, high energy, high vitamin and mineral, and low-fat meals are recommended to efficiently improve the protein and energy malnutrition while resting the intestinal tract. In CD, low-fat diets and lowresidue foods are the bases; however, evidence regarding the type and dose of adequate fat and dietary fiber remains unclear.

\section{(1) Fatty acid}

High fat diets have been shown to increase the severity of colitis in mice, while plant polysaccharides and resistant fiber plant components have been shown to reduce UC symptoms. It is believed that the mechanism increases the production of short-chain fatty acids and increases the barrier function by serving as an energy source for intestinal mucosa. Butyrate (BT) especially regulates innate and adaptive immune cell generation and function. BT has an anti-inflammatory effect by inhibiting the recruitment and proinflammatory activity of neutrophils, macrophages, dendritic cells, and effector $T$ cells and by increasing the number and activity of regulatory $T$ cells. Gut microbial dysbiosis has reduced BT concentration that is linked to a marked increase in the number of proinflammatory immune cells in the gut mucosa in patients with IBD. The antiinflammatory effect of BT includes inhibiting the recruitment and proinflammatory activity of neutrophils, macrophages, dendritic cells, and effector $\mathrm{T}$ cells and increasing the number and activity of regulatory $T$ cells. Therefore, gut microbial dysbiosis has been shown to reduce BT concentration that is linked to a marked increase in the number of proinflammatory immune cells in the gut mucosa in patients with $\operatorname{IBD}^{[110,111]}$. High intake of dietary $n-3$ PUFA is associated with decreased risk of UC and CD ${ }^{[12,113]}$. A case-control study has suggested that the association between dietary $n 3:$ n6 PUFA intake and risk of UC may be modified variants at CYP4F3. High n3: n6 PUFA intake was associated with reduced risk of $U C$ in individuals with GG/AG genotype at a single 
nucleotide polymorphism in CYP4F3 ${ }^{[114]}$. Barnes $E L$ et al. ${ }^{[115]}$ reported that increased intake of multiple fatty acids was associated with increasing odds of relapse and specific fatty acids, i.e., myristic acid (commonly found in palm oil, coconut oil, and dairy fats) that may associate with an increasing risk of flare. $n-6$ fatty acids found in the fat oils of beef, pork, and poultry are limited because they will exacerbate inflammation, whereas those found in fish oil tend to reduce inflammatory leukotrienes and exert anti-inflammatory action. A RCT found no effects on n-3 fatty acid supplementation during the 1 year prevention of $C D$ relapse ${ }^{[116]}$, whereas other studies found it to be associated with absence of $C D$ relapse ${ }^{[117]}$.

\section{(2) Amino acids}

Amino acids have been reported to have an antiinflammatory effect on intestinal inflammation animal model, with glutamine as the most common. The effects of glutamine on enteritis were confirmed by its oral administration to trinitrobenzenesulfonic acid-induced enteritis rats ${ }^{[18]}$ and dextran sulfate sodium (DSS)induced enteritis rats ${ }^{[119]}$. Its scavenger effect on intestinal epithelial cells, improvement of barrier function, and inhibition of local inflammatory cytokine production are considered as the mechanism of action. Biogenic amines such as histamine, an important regulator of physiological gut functions, might also affect the immune response in patients with IBD. Histamine is derived from the amino acid histidine, and dietary histidine can reduce symptoms of immune-mediated colitis in mice. Andou et al. ${ }^{[120]}$ revealed that histidine suppresses the production of TNFa from macrophages through NF-kB signal suppression. Tryptophan is a precursor of an immunomodulating biogenic amine that promote T-regulatory cells development and immune tolerance. Additionally, threonine could enhance barrier function by enhancing the production of intestinal mucus. Tryptophan and threonine supplements have been shown to reduce colitis symptoms in mice. Glycine has been reported to inhibit the production of local inflammatory cytokines and chemokines against DSS-induced enteritis rats, thereby preventing the progression of enteritis ${ }^{[121]}$.

\section{(3) Specific-carbohydrate diet}

Certain carbohydrate diets, involving strict restriction of cereals, most dairy products, and refined sugars, are of interest in the medical community, but has not been widely studied. Evidence on the role of poorly absorbed shortchain carbohydrates on gastrointestinal symptoms increased in the 1980s. These incompletely absorbed carbohydrates and polyols are summarized in the term FODMAPs, which is an acronym that stands for: Fermentable Oligosaccharides, Disaccharides, Monosaccharides and Polyols ${ }^{[122]}$. FODMAPs can also induce gastrointestinal symptoms when fermented by intestinal bacteria and produce large amounts of gas ${ }^{[123,124]}$. Several trials have demonstrated the effects of FODMAP-reduced diet for the treatment of irritable bowel syndrome $(\text { IBS })^{[125]}$. As patients with IBD experienced IBSlike symptoms, a FODMAP-reduced diet might also be a therapeutic option ${ }^{[122,126]}$.

(4) Prebiotics

Prebiotics are indigestible foods that selectively promote the growth of effective gut bacteria and promote the host's health status. Some oligosaccharides and dietary fibers are food ingredients qualified as prebiotics, such as the growth promoting effects of Lactobacillus and Bifidobacteria ${ }^{[127]}$. Dietary fiber undergoes fermentation by the intestinal bacteria and produces SCFAs such as BT and propionic acid acetate and becomes an energy source of mucosal epithelial cells and small intestine villi, activating specific intestinal bacteria. Dietary fiber intake stimulates the intestinal tract by promoting secretion of intestinal motility and digestive juice, which can cause symptoms such 
as diarrhea and abdominal pain. Therefore, low residual food has been recommended in patients with IBD. However, as its physiological effects become apparent, the views on dietary fiber for patients with IBD have also changed. For UC, Mitsuyama et al. ${ }^{[128]}$ reported the clinical utility by administering a powder derived from malt rich in glutamine and dietary fiber to mildto-moderate UC.

Heaton et al. ${ }^{[129]}$ restricted intake of refined carbohydrates against CD; CD patients who ingested diet rich in dietary fiber such as raw vegetables and fruits had shorter hospitalization for patients with $C D$ who ingested low residual food. In addition, Ananthakrishnan et al. ${ }^{[130]}$ reported that long- term intake of dietary fiber, particularly from fruit, is associated with risk of CD but not UC. On the other hand, Levenstein et al. ${ }^{[131]}$ divided the patients with $C D$ without stenosis into low residual food group and normal food group, including fresh vegetables and fruits; there was no difference in symptoms, need for hospitalization, complication, nutritional status, and recurrence after surgery. Although it should be avoided when there is active lesion or stenosis, intake of dietary fiber is useful for improving the patient's quality of life.

(5) Probiotics

Probiotics are defined as live bacteria showing beneficial effects on the host when ingested at an appropriate amount; the most common are Lactobacillus and Bifidobacteria. Probiotics can reduce harmful microorganisms and maintain the microbial balance inside the gut by blocking the site of adhesion, competing for nutrients, and killing pathogenic microorganisms ${ }^{[132]}$. In addition, probiotic bacteria can function as antiinflammatory agents by modulating the NF-kB signaling pathway, inflammatory cytokines, and regulatory T-cell response ${ }^{[133]}$. VSL\#3 is as a probiotic with UC remission induction effect $^{[134,135]}$. In patients with mild-to-moderate UC, VSL\#3 is said to have some effects on reducing the disease activity ${ }^{[136]}$. Takeda et al. ${ }^{[137]}$ reported immunoregulatory effect of Bifidobacterium longum in UC. In addition, it was demonstrated that Bifidobacterium longum 536 (BB536) improves UC disease activity index, endoscopic index, and Mayo subscores in a randomized controlled trial[138]. Taken together, some probiotics could be a therapeutic option in IBD treatments.

\section{CONCLUSION}

Enternal and parenteral nutrition for patients with IBD is effective in some condition. Several food components such as vitamin D, n-3 PUFA, and amino acids have been effective in treating gastrointestinal inflammation and modulating factors involved in the pathogenesis of IBD. Functional foods can modulate inflammatory cytokines and can interact with the immune system to produce anti-inflammatory functions against IBD. Furthermore, probiotics and prebiotics have anti-inflammatory effects against IBD. Based on these clinical data, nutritional treatment may induce and maintain remission especially in patients with CD. On the other hand, its evidence in UC remains unclear.

In recent years, biologics have appeared one after another and medical treatment in IBD has 
been diversified. However, we are required to recognize the importance of the nutritional and dietary treatment once again in the era of biologics, and to accumulate further evidence in the future.

Author Contributions: Conceptualization, Y.Y., T.I. and H.N.; Investigation, Y.Y. and T.I.; Writing-Original Draft Preparation, Y.Y. and T.I.; Writing-Review \& Editing, H.N.; Supervision, H.N.; Funding Acquisition, T.I. and H.N.

Conflict-of-interest statement: No potential conflicts of interest.

\section{REFERENCES}

1. Zhang YZ, Li YY. Inflammatory bowel disease: pathogenesis. World J Gastroenterol 2014; 20: 91-99. PMID: $24415861 \quad$ DOI: 10.3748/wjg.v20.i1.91]

2. Xavier RJ, Podolsky DK. Unravelling the pathogenesis of inflammatory bowel disease. Nature 2007; 448: 427-434 [PMID: 17653185 DOI: 10.1038/nature06005]

3. Sanderson IR. Growth problems in children with IBD. Nat Rev Gastroenterol Hepatol 2014; 11: 601-610 [PMID: 24957008 DOI: 10.1038/nrgastro.2014.102]

4. Cholapranee A, Hazlewood, GS, Kaplan GG, Peyrin-Biroulet L, Ananthakrishnan AN. Systematic review with meta-analysis: comparative efficacy of biologics for induction and maintenance of mucosal healing in Crohn's disease and ulcerative colitis controlled trials. Aliment Pharmacol Ther 2017; 45: 12911302 [PMID: 28326566 DOI: 10.1111/apt.14030]

5. Lee D, Albenberg L, Compher C, Baldassano R, Piccoli D, Lewis JD, Wu GD. Diet in the pathogenesis and treatment of inflammatory bowel diseases. Gastroenterology 2015; 148: 1087-1106 [PMID: 25597840 DOI: 10.1053/j.gastro.2015.01.007]

6. Kaplan GG. The global burden of IBD: from 2015 to 2025. Nat Rev Gastroenterol Hepatol 2015; 12: 720-727 [PMID: 26323879 DOI: 10.1038/nrgastro.2015.150]

7. Ananthakrishnan AN. Epidemiology and risk factors for IBD. Nat Rev Gastroenterol Hepatol 2015; 12: 205-217 [PMID: 25732745 DOI: 10.1038/nrgastro.2015.34]

8. Ogura Y, Bonen DK, Inohara N, Nicolae DL, Chen FF, Ramos R, Britton H, Moran T, Karaliuskas R, Duerr RH, Achkar JP, Brant SR, Bayless TM, Kirschner BS, Hanauer SB, Nunez G, Cho JH. A frameshift mutation in NOD2 associated with susceptibility to Crohn's disease. Nature 2001; 411: 603-606 [PMID: 11385577 DOI: 10.1038/35079114]

9. Lynch SV, Pedersen O. The Human Intestinal Microbiome in Health and Disease. $\mathrm{N}$ Engl $\mathrm{J}$ Med 2016; 375: 2369-2379 [PMID: 27974040 DOI: 10.1056/NEJMra1600266]

10. Brestoff JR, Artis D. Commensal bacteria at the interface of host metabolism and the immune system. Nat Immunol 2013; 14: 676-684 [PMID: 23778795 DOI: 10.1038/ni.2640]

11. Yao CK, Muir JG, Gibson PR. Review article: insights into colonic protein fermentation, its modulation and potential health implications. Aliment Pharmacol Ther 2016; 43: 181-196 [PMID: 26527169 DOI: 10.1111/apt.13456] 
Yoshihiro Yokoyama et al., OJGH, 2019 2:20

12. Wang D, Dubois RN. Eicosanoids and cancer. Nat Rev Cancer 2010; 10: 181-193 [PMID: 20168319 DOI: 10.1038/nrc2809]

13. Coeffier M, Marion-Letellier $R$, Dechelotte $P$. Potential for amino acids supplementation during inflammatory bowel diseases. Inflamm Bowel Dis 2010; 16: 518-524 [PMID: 19572337 DOI: 10.1002/ibd.21017]

14. Cantorna MT, Zhu Y, Froicu M, Wittke A. Vitamin D status, 1,25-dihydroxyvitamin D3, and the immune system. Am J Clin Nutr 2004; 80: 1717s1720s [PMID: 15585793 DOI: 10.1093/ajcn/80.6.1717S]

15. Desai MS, Seekatz AM, Koropatkin NM, Kamada N, Hickey CA, Wolter M, Pudl NA, Kitamoto S, Terrapon N, Muller A, Young VB, Henrissat B, Wilmes P, Stappenbeck TS, Nunez G, Martens EC. A Dietary Fiber-Deprived Gut Microbiota Degrades the Colonic Mucus Barrier and Enhances Pathogen Susceptibility. Cell 2016; 167: 1339-1353. e21 [PMID: 27863247 DOI: 10.1016/j.cell.2016.10.043]

16. Ivanov II, Atarashi K, Manel N, Brodie EL, Shima T, Karaoz U, Wei D, Goldfarb KC, Santee CA, Lynch SV, Tanoue T, Imaoka A, Itoh K, Takeda K, Umesaki Y, Honda K, Littman DR. Induction of intestinal Th17 cells by segmented filamentous bacteria. Cell 2009; 139: 485-498 [PMID: 19836068 DOI: 10.1016/j.cell.2009.09.033]

17. Piechota-Polanczyk A, Fichna J. Review article: the role of oxidative stress in pathogenesis and treatment of inflammatory bowel diseases. Naunyn Schmiedebergs Arch
Pharmacol 2014; 387: 605-620 [PMID: 24798211

DOI: $10.1007 / \mathrm{s} 00210-014-0985-1]$

18. Lissner D, Schumann M, Batra A, Kredel LI, Kuhl AA, Erben U, May C, Schulzke JD, Siegmund B. Monocyte and M1 Macrophage-induced Barrier Defect Contributes to Chronic Intestinal Inflammation in IBD. Inflamm Bowel Dis 2015; 21: 1297-1305 [PMID: 25901973 DOI: 10.1097/mib.0000000000000384]

19. Rubio CA, Langner C, Schmidt PT. Partial to complete abrogation of the subepithelial macrophage barrier against the gut microbiota in patients with ulcerative colitis and Crohn's colitis. Histopathology 2018; 72: 580-587 [PMID: 29023984 DOI: 10.1111/his.13417]

20. Matsuoka K, Kanai T. The gut microbiota and inflammatory bowel disease. Semin Immunopathol 2015; 37: 47-55 [PMID: 25420450 DOI: $10.1007 / \mathrm{s} 00281-014-0454-4]$

21. Thibault R, Blachier F, Darcy-Vrillon B, de Coppet P, Bourreille A, Segain JP. Butyrate utilization by the colonic mucosa in inflammatory bowel diseases: a transport deficiency. Inflamm Bowel Dis 2010; 16: 684-695 [PMID: 19774643 DOI: 10.1002/ibd.21108]

22. Sartor RB. Microbial influences in inflammatory bowel diseases. Gastroenterology 2008; 134 : 577-594 [PMID: 18242222 DOI: 10.1053/j.gastro.2007.11.059]

23. Gerasimidis K, McGrogan P, Edwards CA. The aetiology and impact of malnutrition in paediatric inflammatory bowel disease. J Hum Nutr Diet 2011; 24: 313-326 [PMID: 21564345 DOI: 10.1111/j.1365-277X.2011.01171.x] 
24. Motil KJ, Grand RJ, Davis-Kraft L, Ferlic LL, Smith, EO. Growth failure in children with inflammatory bowel disease: a prospective study. Gastroenterology 1993; 105 : 681-691 [PMID: 8359640]

25. Murawska N, Fabisiak A, Fichna J. Anemia of Chronic Disease and Iron Deficiency Anemia in Inflammatory Bowel Diseases: Pathophysiology, Diagnosis, and Treatment. Inflamm Bowel Dis 2016; 22: 1198-1208 [PMID: 26818422 DOI: 10.1097/mib.0000000000000648]

26. Eriksson C, Henriksson I, Brus O, Zhulina Y, Nyhlin N, Tysk C, Montgomery S, Halfvarson J. Incidence, prevalence and clinical outcome of anaemia in inflammatory bowel disease: a population-based cohort study. Aliment Pharmacol Ther 2018; 48: 638-645 [PMID: 30069892 DOI: 10.1111/apt.14920]

27. Nielsen $\mathrm{OH}$, Ainsworth $\mathrm{M}$, Coskun M, Weiss G. Management of Iron-Deficiency Anemia in Inflammatory Bowel Disease: A Systematic Review. Medicine (Baltimore). 2015; 94: e963 [PMID: $26061331 \quad$ DOI: 10.1097/md.0000000000000963]

28. Pan Y, Liu Y, Guo H, Jabir MS, Liu X, Cui W, Li D. Associations between Folate and Vitamin B12 Levels and Inflammatory Bowel Disease: A MetaAnalysis. Nutrients 2017; 9: pii: E382 [PMID: 28406440 DOI: 10.3390/nu9040382]

29. Hyams JS, Wyzga N, Kreutzer DL, Justinich CJ, Gronowicz GA. Alterations in bone metabolism in children with inflammatory bowel disease: An in vitro study. J Pediatr Gastroenterol Nutr 1997; 24: 289-295 [PMID: 9138175 DOI: 10.1097/00005176-199703000-00011]
30. Walther F, Fusch C, Radke M, Beckert S, Findeisen A. Osteoporosis in pediatric patients suffering from chronic inflammatory bowel disease with and without steroid treatment. $\mathrm{J}$ Pediatr Gastroenterol Nutr 2006; 43: 42-51 [PMID: $16819376 \quad$ DOI: 10.1097/01.mpg.0000228105.91240.80]

31. Ezzat $Y$, Hamdy $K$. The frequency of low bone mineral density and its associated risk factors in patients with inflammatory bowel diseases. Int $\mathrm{J}$ Rheum Dis 2010; 13: 259-265 [PMID: 20704624 DOI: 10.1111/j.1756-185X.2010.01542.x]

32. Wada Y, Hisamatsu T, Naganuma M, Matsuoka K, Okamoto S, Inoue N, Yajima T, Kouyama K, Iwao Y, Ogata H, Hibi H, Abe T, Kanai T. Risk factors for decreased bone mineral density in inflammatory bowel disease: A cross-sectional study. Clin Nutr 2015; 34: 1202-1209 [PMID: 25618799 DOI: 10.1016/j.clnu.2015.01.003]

33. Adams DW, Gurwara S, Silver HJ, Horst SN, Beaulieu DB, Schwartz DA, Seidner DL. Sarcopenia Is Common in Overweight Patients with Inflammatory Bowel Disease and May Predict Need for Surgery. Inflamm Bowel Dis 2017; 23: 1182-1186 [PMID: 28410342 DOI: 10.1097/MIB.0000000000001128]

34. Mager DR, Carroll MW, Wine E, Siminoski K, MacDonald K, Kluthe CL, Medvedev P, Chen M, Wu J, Turner JM, Huynh HQ. Vitamin D status and risk for sarcopenia in youth with inflammatory bowel diseases. Eur J Clin Nutr 2018; 72: 623626 [PMID: 29391593 DOI: 10.1038/s41430018-0105-2]

35. Bamba S, Sasaki M, Takaoka A, Takahashi K, Imaeda $\mathrm{H}$, Nishida $\mathrm{A}$, Inatomi $\mathrm{O}$, Sugimoto $\mathrm{M}$, 
Yoshihiro Yokoyama et al., OJGH, 2019 2:20

Andoh A. Sarcopenia is a predictive factor for intestinal resection in admitted patients with Crohn's disease. Plos One 2017; 12: e0180036 [PMID: $28644887 \quad$ DOI: 10.1371/journal.pone.0180036]

36. Pedersen M, Cromwell J, Nau P. Sarcopenia is a Predictor of Surgical Morbidity in Inflammatory Bowel Disease. Inflamm Bowel Dis 2017; 23: 1867-1872 [PMID: 28604415 DOI: 10.1097/MIB.0000000000001166]

37. Bryant RV, Ooi S, Schultz CG, Goess C, Grafton R, Hughes J, Lim A, Bartholomeusz FD, Andrews JM. Low muscle mass and sarcopenia: common and predictive of osteopenia in inflammatory bowel disease. Aliment Pharmacol Ther 2015; 41: 895-906 [PMID: 25753216 DOI: 10.1111/apt.13156]

38. Holt DQ, Varma P, Strauss BJG, Rajadurai AS, Moore GT. Low muscle mass at initiation of antiTNF therapy for inflammatory bowel disease is associated with early treatment failure: a retrospective analysis. Eur J Clin Nutr 2017; 71: 773-777 [PMID: 28225051 DOI: 10.1038/ejcn.2017.10]

39. Fabisiak N, Fabisiak A, Watala C, Fichna J. Fatsoluble Vitamin Deficiencies and Inflammatory Bowel Disease: Systematic Review and MetaAnalysis. J Clin Gastroenterol 2017; 51: 878-889 [PMID: 28858940

DOI:

\section{$10.1097 / \mathrm{mcg} .0000000000000911]$}

40. Ananthakrishnan AN, Khalili H, Higuchi LM, Bao Y, Korzenik JR, Giovannucci EL, Richter JM, Fuchs CS, Chan AT. Higher Predicted Vitamin D Status Is Associated With Reduced Risk of Crohn's Disease. Gastroenterology 2012; 142:
482-489

[PMID:

22155183

DOI: 10.1053/j.gastro.2011.11.040]

41. Garg M, Hendy P, Ding JN, Shaw S, Hold G, Hart A. The Effect of Vitamin D on Intestinal Inflammation and Faecal Microbiota in Patients with Ulcerative Colitis. J Crohns Colitis 2018; 12: 963-972 [PMID: 29726893 DOI: 10.1093/eccojcc/jjy052]

42. Vagianos K, Bector S, McConnell J, Bernstein CN. Nutrition assessment of patients with inflammatory bowel disease. J Parenter Enteral Nutr 2007; 31: 311-319 [PMID: 17595441 DOI: $10.1177 / 0148607107031004311]$

43. Siva S, Rubin DT, Gulotta G, Wroblewski K, Pekow J. Zinc Deficiency is Associated with Poor Clinical Outcomes in Patients with Inflammatory Bowel Disease. Inflamm Bowel Dis 2017; 23: 152-157 [PMID: 27930412 DOI: 10.1097/MIB.0000000000000989]

44. Ruemmele FM, Veres G, Kolho KL, Griffiths A, Levine A, Escher JC, Amil Dias J, Barabino A, Braegger CP, Bronsky J, Buderus S, Martin-deCarpi J, De Ridder L, Fagerberg UL, Hugot JP, Kierkus J, Kolacek S, Koletzko S, Lionetti P, Miele E, Navas Lopez VM, Paerregaard A, Russell RK, Serban DE, Shaoul R, Van Rheenen P, Veereman $G$, Weiss $B$, Wilson $D$, Dignass $A$, Eliakim A, Winter H, Turner D. Consensus guidelines of ECCO/ESPGHAN on the medical management of pediatric Crohn's disease. J Crohns Colitis 2014; 8: 1179-1207 [PMID: 24909831 DOI: 10.1016/j.crohns.2014.04.005]

45. Kleinman RE, Baldassano RN, Caplan A, Griffiths AM, Heyman MB, Issenman RM, Lake AM, Motil KJ, Seidman E, Udall JN. Nutrition OJGH: https://escipub.com/open-journal-of-gastroenterology-and-hepatology/ 
Yoshihiro Yokoyama et al., OJGH, 2019 2:20

support for pediatric patients with inflammatory bowel disease: a clinical report of the North American Society for Pediatric Gastroenterology, Hepatology And Nutrition. J Pediatr Gastroenterol Nutr 2004; 39: 15-27 [PMID: 15187775]

46. Day AS, Burgess L. Exclusive enteral nutrition and induction of remission of active Crohn's disease in children. Expert Rev Clin Immunol 2013; 9: 375-383 [PMID: 23557272 DOI: 10.1586/eci.13.12]

47. Harries AD, Jones LA, Danis V, Fifield R, Heatley RV, Newcombe RG, Rhodes J. Controlled trial of supplemented oral nutrition in Crohn's disease. Lancet 1983; 1: $\quad$ 887-890 $\quad$ [PMID: 6132218]

48. O'Morain C, Segal AW, Levi AJ. Elemental diet as primary treatment of acute Crohn's disease: a controlled trial. $\mathrm{Br}$ Med J (Clin Res Ed). 1984; 288: 1859-1862 [PMID: 1441790]

49. Giaffer MH, North G, Holdsworth CD. Controlled trial of polymeric versus elemental diet in treatment of active Crohn's disease. Lancet 1990; 335: 816-819 [PMID: 1969560]

50. Lochs H, Steinhardt HJ, Klaus-Wentz B, Zeitz M, Vogelsang $\mathrm{H}$, Sommer $\mathrm{H}$, Fleig WE, Bauer $\mathrm{P}$, Schirrmeister J, Malchow H. Comparison of enteral nutrition and drug treatment in active Crohn's disease. Results of the European Cooperative Crohn's Disease Study. IV. Gastroenterology 1991; 101: 881-888 [PMID: 1679736]

51. Rigaud D, Cosnes J, Le Quintrec Y, Rene E, Gendre JP, Mignon M. Controlled trial comparing two types of enteral nutrition in treatment of active Crohn's disease: elemental versus polymeric diet. Gut 1991; 32: 1492-1497 [PMID: 1773955]

52. Lindor KD, Fleming CR, Burnes JU, Nelson JK, Ilstrup DM. A randomized prospective trial comparing a defined formula diet, corticosteroids, and a defined formula diet plus corticosteroids in active Crohn's disease. Mayo Clin Proc 1992; 67: 328-333 [PMID: 1548947]

53. Gonzalez-Huix F, Fernandez-Banares F, EsteveComas M, Abad-Lacruz A, Cabre E, Acero D, Figa M, Guilera M, Humbert P, de Leon R. Enteral versus parenteral nutrition as adjunct therapy in acute ulcerative colitis. Am J Gastroenterol 1993; 88: 227-232 [PMID: 8424426]

54. Gorard DA, Hunt JB, Payne-James JJ, Palmer KR, Rees RG, Clark ML, Farthing MJ, Misiewicz JJ, Silk DB. Initial response and subsequent course of Crohn's disease treated with elemental diet or prednisolone. Gut 1993; 34: 1198-1202 [PMID: 8406153]

55. Fernandez-Banares F, Cabre E, Esteve-Comas M, Gassull MA. How effective is enteral nutrition in inducing clinical remission in active Crohn's disease? A meta-analysis of the randomized clinical trials. JPEN J Parenter Enteral Nutr 1995; 19: 356-364 [PMID: 8577011 DOI: 10.1177/0148607195019005356]

56. Griffiths AM, Ohlsson A, Sherman PM, Sutherland LR. Meta-analysis of enteral nutrition as a primary treatment of active Crohn's disease. Gastroenterology 1995; 108: 10561067 [PMID: 7698572] 
57. Zoli G, Care M, Parazza M, Spano C, Biagi PL, Bernardi M, Gasbarrini G. A randomized controlled study comparing elemental diet and steroid treatment in Crohn's disease. Aliment Pharmacol Ther 1997; 11: 735-740 [PMID: 9305483]

58. Heuschkel RB, Menache CC, Megerian JT, Baird $A E$. Enteral nutrition and corticosteroids in the treatment of acute Crohn's disease in children. J Pediatr Gastroenterol Nutr 2000; 31: 8-15 [PMID: 10896064]

59. Verma S, Brown S, Kirkwood B, Giaffer MH. Polymeric versus elemental diet as primary treatment in active Crohn's disease: a randomized, double-blind trial. Am J Gastroenterol 2000; 95: 735-739 [PMID: $10719270 \quad$ DOI: $\quad 10.1111 / \mathrm{j} .1572-$ 0241.2000.01527.x]

60. Ludvigsson JF, Krantz M, Bodin L, Stenhammar L, Linquist B. Elemental versus polymeric enteral nutrition in paediatric Crohn's disease: a multicentre randomized controlled trial. Acta Paediatr 2004; 93: 327-335 [PMID: 15124834]

61. Grover Z, Muir R, Lewindon P. Exclusive enteral nutrition induces early clinical, mucosal and transmural remission in paediatric Crohn's disease. J Gastroenterol 2014; 49: 638-645 [PMID: 23636735 DOI: 10.1007/s00535-0130815-0]

62. Sigall-Boneh R, Pfeffer-Gik T, Segal I, Zangen T, Boaz M, Levine A. Partial enteral nutrition with a Crohn's disease exclusion diet is effective for induction of remission in children and young adults with Crohn's disease. Inflamm Bowel
Dis 2014; 20: 1353-1360 [PMID: 24983973 DOI: 10.1097/mib.0000000000000110]

63. Swaminath A, Feathers A, Ananthakrishnan AN, Falzon L, Li FS. Systematic review with metaanalysis: enteral nutrition therapy for the induction of remission in paediatric Crohn's disease. Aliment Pharmacol Ther 2017; 46: 645656 [PMID: 28815649 DOI: 10.1111/apt.14253]

64. Yang Q, Gao X, Chen H, Li M, Wu X, Zhi M, Lan P, Hu P. Efficacy of exclusive enteral nutrition in complicated Crohn's disease. Scand J Gastroenterol 2017; 52: 995-1001 [PMID: 28598298 DOI:

10.1080/00365521.2017.1335770]

65. Luo Y, Yu J, Lou J, Fang Y, Chen J. Exclusive Enteral Nutrition versus Infliximab in Inducing Therapy of Pediatric Crohn's Disease. Gastroenterol Res Pract 2017; 2017: 6595048 [PMID: 28928769 DOI: $10.1155 / 2017 / 6595048]$

66. Connors J, Basseri S, Grant A, Giffin N, Mahdi G, Noble A, Rashid M, Otley A, Van Limbergen J. Exclusive Enteral Nutrition Therapy in Paediatric Crohn's Disease Results in Long-term Avoidance of Corticosteroids: Results of a Propensity-score Matched Cohort Analysis. J Crohns Colitis 2017; 11: 1063-1070 [PMID: 28575325 DOI: 10.1093/ecco-jcc/jjx060]

67. Narula N, Dhillon A, Zhang D, Sherlock ME, Tondeur M, Zachos M. Enteral nutritional therapy for induction of remission in Crohn's disease. Cochrane Database Syst Rev 2018; 4: Cd000542 [PMID: 29607496 DOI: 10.1002/14651858.CD000542.pub3] 
68. Wilschanski M, Sherman P, Pencharz P, Davis L, Corey M, Griffiths A. Supplementary enteral nutrition maintains remission in paediatric Crohn's disease. Gut 1996; 38: 543-548 [PMID: 8707085]

69. Esaki M, Matsumoto T, Nakamura S, Yada S, Fujisawa $\mathrm{K}$, Jo $\mathrm{Y}$, lida $\mathrm{M}$. Factors affecting recurrence in patients with Crohn's disease under nutritional therapy. Dis Colon Rectum 2006; 49: S68-74 [PMID: 17106818 DOI: 10.1007/s10350006-0692-1]

70. Takagi S, Utsunomiya K, Kuriyama S, Yokoyama H, Takahashi S, Iwabuchi M, Takahashi H, Kinouchi Y, Hiwatashi N, Funayama Y, Sasaki I, Tsuji I, Shimosegawa T. Effectiveness of an 'half elemental diet' as maintenance therapy for Crohn's disease: A randomized-controlled trial. Aliment Pharmacol Ther 2006; 24: 13331340 [PMID: 17059514 DOI: 10.1111/j.13652036.2006.03120.x]

71. Yamamoto $T$, Nakahigashi $M$, Umegae $S$, Matsumoto K. Enteral nutrition for the maintenance of remission in Crohn's disease: a systematic review. Eur J Gastroenterol Hepatol 2010; 22: 1-8 [PMID: 19707151 DOI: 10.1097/MEG.0b013e32832c788c]

72. Hanai $\mathrm{H}$, lida $\mathrm{T}$, Takeuchi $\mathrm{K}$, Arai $\mathrm{H}$, Arai $\mathrm{O}$, Abe J, Tanaka T, Maruyama Y, Ikeya K, Sugimoto K, Nakamura T, Nakamura K, Watanabe F. Nutritional therapy versus 6-mercaptopurine as maintenance therapy in patients with Crohn's disease. Dig Liver Dis 2012; 44: 649-654 [PMID: 22542605 DOI: 10.1016/j.dld.2012.03.007]

73. Duncan H, Buchanan E, Cardigan T, Garrick V, Curtis L, McGrogan P, Barclay A, Russell RK. A retrospective study showing maintenance treatment options for paediatric $C D$ in the first year following diagnosis after induction of remission with EEN: supplemental enteral nutrition is better than nothing! BMC Gastroenterol 2014; 14: 50 [PMID: 24645851 DOI: 10.1186/1471-230x-14-50]

74. Grover Z, Lewindon P. Two-Year Outcomes After Exclusive Enteral Nutrition Induction Are Superior to Corticosteroids in Pediatric Crohn's Disease Treated Early with Thiopurines. Dig Dis Sci 2015; 60: 3069-3074 [PMID: 26038093 DOI: 10.1007/s10620-015-3722-9]

75. Kang Y, Kim S, Kim SY, Koh H. Effect of shortterm partial enteral nutrition on the treatment of younger patients with severe Crohn's disease. Gut Liver 2015; 9: 87-93 [PMID: 25170058 DOI: 10.5009/gnl13345]

76. El-Matary W, Otley A, Critch J, Abou-Setta AM. Enteral Feeding Therapy for Maintaining Remission in Crohn's Disease: A Systematic Review. JPEN J Parenter Enteral Nutr 2017; 41: 550-561 [PMID: 26645668 DOI: $10.1177 / 0148607115621051]$

77. Akobeng AK, Zhang D, Gordon M, MacDonald JK. Enteral nutrition for maintenance of remission in Crohn's disease. Cochrane. Database. Syst. Rev. 2018; 8: CD005984 [PMID: 30098021 DOI: 10.1002/14651858.CD005984.pub3]

78. Ikeuchi H, Yamamura T, Nakano H, Kosaka T, Shimoyama T, Fukuda Y. Efficacy of nutritional therapy for perforating and non-perforating Crohn's disease. Hepatogastroenterology 2004; 51: 1050-1052 [PMID: 15239244] OJGH: https://escipub.com/open-journal-of-gastroenterology-and-hepatology/ 
79. Yamamoto T, Nakahigashi M, Umegae S, Kitagawa T, Matsumoto K. Impact of long-term enteral nutrition on clinical and endoscopic recurrence after resection for Crohn's disease: A prospective, non-randomized, parallel, controlled study. Aliment Pharmacol Ther 2007; 25: 67-72 [PMID: 17229221 DOI: 10.1111/j.13652036.2006.03158.x]

80. Wang H, Zuo L, Zhao J, Dong J, Li Y, Gu L, Gong J, Liu Q, Zhu W. Impact of Preoperative Exclusive Enteral Nutrition on Postoperative Complications and Recurrence After Bowel Resection in Patients with Active Crohn's Disease. World J Surg 2016; 40: 1993-2000 [PMID: 26940580 DOI: $10.1007 / s 00268-016-3488-z]$

81. Brennan GT, Ha I, Hogan C, Nguyen E, Jamal MM, Bechtold ML, Nguyen DL. Does preoperative enteral or parenteral nutrition reduce postoperative complications in Crohn's disease patients: a meta-analysis. Eur J Gastroenterol Hepatol 2018; 30: 997-1002 [PMID: 29738326 DOI: 10.1097/meg.0000000000001162]

82. Klaassen J, Zapata R, Mella JG, Aguayo G, Alvarado D, Espinosa O, Maiz A, Zuniga A, Quintana C. Enteral nutrition in severe ulcerative colitis. Digestive tolerance and nutritional efficiency. Rev Med Chil 1998; 126: 899-904 [PMID: 9830740]

83. Pithadia $A B$, Jain S. Treatment of inflammatory bowel disease. Pharmacol Rep 2011; 63: 629642 [PMID: 21857074]

84. Ito $\mathrm{K}$, Chung $\mathrm{KF}$, Adcock IM. Update on glucocorticoid action and resistance. J Allergy
Clin Immunol 2006; 117: 522-543 [PMID: 16522450 DOI: 10.1016/j.jaci.2006.01.032]

85. Ispas-Szabo P, Friciu MM, Nguyen P, Dumoulin Y, Mateescu MA. Novel self-assembled mesalamine-sucralfate complexes: preparation, characterization, and formulation aspects. Drug Dev Ind Pharm 2016; 42: 1183-1193 [PMID: 26574144 DOI:

\subsection{9/03639045.2015.1118493]}

86. Derkx B, Taminiau J, Radema S, Stronkhorst A, Wortel C, Tytgat G, Vandeventer S. TUMORNECROSIS-FACTOR ANTIBODY TREATMENT IN CROHNS-DISEASE. Lancet 1993; 342: 173174 [PMID: 8101267 DOI: 10.1016/01406736(93)91375-v]

87. Suzuki Y, Motoya S, Hanai H, Matsumoto T, Hibi T, Robinson AM, Mostafa NM, Chao JD, Arora V, Camez A, Thakkar RB, Watanabe M. Efficacy and safety of adalimumab in Japanese patients with moderately to severely active ulcerative colitis. J Gastroenterol 2014; 49: 283-294 [PMID: 24363029 DOI: 10.1007/s00535-013-0922-y]

88. Sandborn WJ, Feagan BG, Marano C, Zhang HY, Strauss R, Johanns J, Adedokun OJ, Guzzo C, Colombel JF, Reinisch W, Gibson PR, Collins J, Jarnerot G, Hibi T, Rutgeerts P, Pursuit-Sc Study Grp. Subcutaneous Golimumab Induces Clinical Response and Remission in Patients With Moderate-to-Severe Ulcerative Colitis. Gastroenterology 2014; 146: 85-95 [PMID: 23735746 DOI: 10.1053/j.gastro.2013.05.048]

89. Feagan BG, Sandborn WJ, Gasink C, Jacobstein D, Lang Y, Friedman JR, Blank MA, Johanns J, Gao LL, Miao Y, Adedokun OJ, Sands BE, OJGH: https://escipub.com/open-journal-of-gastroenterology-and-hepatology/ 
Yoshihiro Yokoyama et al., OJGH, 2019 2:20

Hanauer SB, Vermeire S, Targan S, Ghosh S, de Villiers WJ, Colombel JF, Tulassay Z, Seidler U, Salzberg BA, Desreumaux P, Lee SD, Loftus EVJ, Dieleman LA, Katz S, Rutgeerts P. Ustekinumab as Induction and Maintenance Therapy for Crohn's Disease. N Engl J Med 2016; 375: $1946-$ 1960 [PMID: 27959607 DOI: 10.1056/NEJMoa1602773]

90. Gordon FH, Lai CWY, Hamilton MI, Allison MC, Srivastava ED, Fouweather MG, Donoghue S, Greenlees C, Subhani J, Amlot PL, Pounder RE. A randomized placebo-controlled trial of a humanized monoclonal antibody to alpha 4 integrin in active Crohn's disease. Gastroenterology 2001; 121： 268-274 [PMID: 11487536]

91. Sandborn WJ, Su C, Sands BE, D'Haens GR, Vermeire S, Schreiber S, Danase S, Feagan BG, Reinisch W, Niezychowski W, Friedman G, Lawendy N, Yu D, Woodworth D, Mukherjee A, Zhang $\mathrm{H}$, Healey $\mathrm{P}$, Panes J. Tofacitinib as Induction and Maintenance Therapy for Ulcerative Colitis. N Engl J Med 2017; 376: 17231736 [PMID: 28467869 DOI: 10.1056/NEJMoa1606910]

92. Matsumoto $T$, lida $M$, Kohgo $Y$, Imamura $A$, Kusugami K, Nakano H, Fujiyama Y, Matsu T, Hibi T. Therapeutic efficacy of infliximab on active Crohn's disease under nutritional therapy. Scand J Gastroenterol 2005; 40: 1423-1430 [PMID: 16316890 DOI: 10.1080/00365520510023639]

93. Tanaka T, Takahama K, Kimura T, Mizuno T, Nagasaka M, Iwata K, Nakano H, Muramatsu M, Takazoe M. Effect of concurrent elemental diet on infliximab treatment for Crohn's disease. J
Gastroenterol Hepatol 2006; 21: 1143-1149 [PMID: 16824066 DOI: 10.1111/j.14401746.2006.04317.x]

94. Yamamoto T, Nakahigashi $M$, Umegae $S$, Matsumoto K. Prospective clinical trial: enteral nutrition during maintenance infliximab in Crohn's disease. J Gastroenterol 2010; 45: 24-29 [PMID: 19798465 DOI: 10.1007/s00535-009-0136-5]

95. Sazuka S, Katsuno T, Nakagawa T, Saito M, Saito K, Matsumura T, Arai M, Sato T, Yokosuka O. Concomitant use of enteral nutrition therapy is associated with sustained response to infliximab in patients with Crohn's disease. Eur J Clin Nutr 2012; 66: 1219-1223 [PMID: 23010687 DOI: 10.1038/ejcn.2012.120]

96. Hirai F, Ishihara H, Yada S, Esaki M, Ohwan T, Nozaki R, Ashizuka S, Inatsu H, Ohi H, Aoyagi K, Mizuta Y, Matsumoto T, Matsui T. Effectiveness of concomitant enteral nutrition therapy and infliximab for maintenance treatment of Crohn's disease in adults. Dig Dis Sci 2013; 58: 13291334 [PMID: 22926500 DOI: 10.1007/s10620012-2374-2]

97. Kamata N, Oshitani N, Watanabe K, Hosomi S, Noguchi A, Yukawa T, Yamagami H, Shiba M, Tanigawa T, Watanabe T, Tominaga K, Fujiwara Y, Arakawa T. Efficacy of concomitant elemental diet therapy in scheduled infliximab therapy in patients with Crohn's disease to prevent loss of response. Dig Dis Sci 2015; 60: 1382-1388 [PMID: 25532505 DOI: 10.1007/s10620-0143493-8]

98. Nguyen DL, Palmer LB, Nguyen ET, McClave SA, Martindale RG, Bechtold ML. Specialized enteral nutrition therapy in Crohn's disease patients on 
Yoshihiro Yokoyama et al., OJGH, 2019 2:20

maintenance infliximab therapy: a metaanalysis. Therap Adv Gastroenterol 2015; 8: 168-175 [PMID: 26136834 DOI: 10.1177/1756283X15578607]

99. Sugita N, Watanabe K, Kamata N, Yukawa T, Otani K, Hosomi S, Nagami Y, Tanaka F, Taira K, Yamagami H, Tanigawa T, Shiba M, Watanabe T, Tominaga K Kabata D, Shintani A, Arakawa T, Fujiwara Y. Efficacy of a concomitant elemental diet to reduce the loss of response to adalimumab in patients with intractable Crohn's disease. J Gastroenterol Hepatol 2018; 33: 631637 [PMID: 28857255 DOI: 10.1111/jgh.13969]

100. Hisamatsu T, Kunisaki R, Nakamura S, Tsujikawa T, Hirai F, Nakase H, Watanabe K, Yokoyama K, Nagahori M, Kanai T, Naganuma M, Michimae H, Andoh A, Yamada A, Yokoyama T, Kamata N, Tanaka S, Suzuki Y, Hibi T, Watanabe M. Effect of elemental diet combined with infliximab dose escalation in patients with Crohn's disease with loss of response to infliximab: CERISIER trial. Intest Res 2018; 16: 494-498 [PMID: 30090050 DOI: 10.5217/ir.2018.16.3.494]

101. Triantafillidis JK, Papalois AE. The role of total parenteral nutrition in inflammatory bowel disease: current aspects. Scand J Gastroenterol 2014; 49: 3-14 [PMID: 24354966 DOI: 10.3109/00365521.2013.860557]

102. Dickinson RJ, Ashton MG, Axon AT, Smith RC, Yeung CK, Hill GL. Controlled trial of intravenous hyperalimentation and total bowel rest as an adjunct to the routine therapy of acute colitis. Gastroenterology 1980; 79: 1199-1204 [PMID: 6777233]
103. Muller JM, Keller HW, Erasmi H, Pichlmaier $H$. Total parenteral nutrition as the sole therapy in Crohn's disease-a prospective study. $\mathrm{Br} \mathrm{J}$ Surg 1983; 70: 40-43 [PMID: 6402050]

104. Ostro MJ, Greenberg GR, Jeejeebhoy KN. Total parenteral nutrition and complete bowel rest in the management of Crohn's disease. J Parenter Enteral Nutr 1985; 9: 280-287 [PMID: 3925172 DOI: $10.1177 / 0148607185009003280]$

105. Mclntyre PB, Powell-Tuck J, Wood SR, LennardJones JE, Lerebours E, Hecketsweiler $P$, Galmiche JP, Colin R. Controlled trial of bowel rest in the treatment of severe acute colitis. Gut 1986; 27: 481-485 [PMID: 3084344]

106. Greenberg GR, Fleming CR, Jeejeebhoy KN, Rosenberg IH, Sales D, Tremaine WJ. Controlled trial of bowel rest and nutritional support in the management of Crohn's disease. Gut 1988; 29: 1309-1315 [PMID: 3143625]

107. Duerksen DR, Nehra V, Bistrian BR, Blackburn GL. Appropriate nutritional support in acute and complicated Crohn's disease. Nutrition 1998; 14: 462-465 [PMID: 9614313]

108. Richman E, Rhodes JM. Review article: evidence-based dietary advice for patients with inflammatory bowel disease. Aliment Pharmacol Ther 2013; 38: 1156-1171 [PMID: 24102340 DOI: 10.1111/apt.12500]

109. Egberg MD, Galanko JA, Barnes EL, Kappelman MD. Thrombotic and Infectious Risks of Parenteral Nutrition in Hospitalized Pediatric Inflammatory Bowel Disease. Inflamm Bowel Dis 2019; 25: 601-609 [PMID 30304444 DOI: 10.1093/ibd/izy298] 
Yoshihiro Yokoyama et al., OJGH, 2019 2:20

110. Scaioli E, Liverani E, Belluzzi A. The Imbalance between n-6/n-3 Polyunsaturated Fatty Acids and Inflammatory Bowel Disease: A Comprehensive Review and Future Therapeutic Perspectives. Int J Mol Sci 2017; 18: pii: E2619 [PMID: 29206211 DOI: 10.3390/ijms18122619]

111. Goncalves P, Araujo JR, Di Santo JP. A CrossTalk Between Microbiota-Derived Short-Chain Fatty Acids and the Host Mucosal Immune System Regulates Intestinal Homeostasis and Inflammatory Bowel Disease. Inflamm Bowel Dis 2018; 24: 558-572 [PMID: 29462379 DOI: 10.1093/ibd/izx029]

112. Scaioli E, Sartini A, Bellanova M, Campieri M, Festi D, Bazzoli F, Belluzzi A. Eicosapentaenoic Acid Reduces Fecal Levels of Calprotectin and Prevents Relapse in Patients With Ulcerative Colitis. Clin Gastroenterol Hepatol 2018; 16: 1268-1275 [PMID: 29391271 DOI: 10.1016/j.cgh.2018.01.036]

113. Sitkin S, Pokrotnieks J. Alterations in Polyunsaturated Fatty Acid Metabolism and Reduced Serum Eicosadienoic Acid Level in Ulcerative Colitis: Is There a Place for Metabolomic Fatty Acid Biomarkers in IBD? Dig Dis Sci 2018; 63: 2480-2481 [PMID: 29987625 DOI: $10.1007 / \mathrm{s} 10620-018-5182-5]$

114. Ananthakrishnan AN, Khalili H, Song MY, Higuchi LM, Lochhead P, Richter JM, Chan AT. Genetic Polymorphisms in Fatty Acid Metabolism Modify the Association Between Dietary n3:n6 Intake and Risk of Ulcerative Colitis: A Prospective Cohort Study. Inflamm Bowel Dis 2017; 23: 1898-1904 [PMID: 28991856 DOI: 10.1097/MIB.0000000000001236]
115. Barnes EL, Nestor M, Onyewadume L, de Silva PS, Korzenik JR, DREAM Investigators. High Dietary Intake of Specific Fatty Acids Increases Risk of Flares in Patients With Ulcerative Colitis in Remission During Treatment With Aminosalicylates. Clin Gastroenterol Hepatol 2017; 15: 1390-1396 [PMID: 28110099 DOI: 10.1016/j.cgh.2016.12.036]

116. Feagan BG, Sandborn WJ, Mittmann U, Bar-Meir S, D'Haens G, Bradette M, Cohen A, Dallaire C, Ponich TP, McDonald JW, Hebuterne X, Pare P, KIvana P, Niv Y, Ardizzone S, Alexeeva O, Rostom A, Kiudelis G, Spleiss J, Gilgen D, Vandervoort MK, Wong CJ, Zou GY, Donner A, Rutgeerts P. Omega-3 free fatty acids for the maintenance of remission in Crohn disease: the EPIC Randomized Controlled Trials. JAMA 2008; 299: 1690-1697 [PMID: 18398081 DOI: 10.1001/jama.299.14.1690]

117. Turner D, Zlotkin SH, Shah PS, Griffiths AM. Omega 3 fatty acids (fish oil) for maintenance of remission in Crohn's disease. Cochrane Database Syst Rev 2009; 1: CD006320 [PMID: 19160277

DOI:

10.1002/14651858.CD006320.pub3]

118. Ameho CK, Adjei AA, Harrison EK, Takeshita K, Morioka T, Arakaki Y, Ito E, Suzuki I, Kulkarni AD, Kawajiri A, Yamamoto S. Prophylactic effect of dietary glutamine supplementation on interleukin 8 and tumour necrosis factor alpha production in trinitrobenzene sulphonic acid induced colitis. Gut 1997; 41: 487-493 [PMID: 9391247]

119. Vicario M, Amat C, Rivero M, Moreto M, Pelegri C. Dietary glutamine affects mucosal functions in rats with mild DSS-induced colitis. J 
Yoshihiro Yokoyama et al., OJGH, 2019 2:20

Nutr 2007; 137: 1931-1937 [PMID: 17634266

DOI: 10.1093/jn/137.8.1931]

120. Andou A, Hisamatsu T, Okamoto S, Chinen H, Kamada N, Kobayashi T, Hashimoto M, Okutsu T, Shimbo K, Takeda T, Matsumoto H, Sato A, Ohtsu H, Suzuki M, Hibi T. Dietary histidine ameliorates murine colitis by inhibition of proinflammatory cytokine production from macrophages. Gastroenterology 2009; 136: 564574. e2 [PMID: 19027739 DOI: 10.1053/j.gastro.2008.09.062]

121. Tsune I, Ikejima K, Hirose M, Yoshikawa M, Enomoto N, Takei Y, Sato N. Dietary glycine prevents chemical-induced experimental colitis in the rat. Gastroenterology 2003; 125: $775-785$ [PMID: 12949723]

122. Gibson PR, Shepherd SJ. Personal view: food for thought-western lifestyle and susceptibility to Crohn's disease. The FODMAP hypothesis. Aliment Pharmacol Ther 2005; 21: 1399-1409 [PMID: 15948806 DOI: 10.1111/j.1365-2036.2005.02506.x]

123. Gearry RB, Irving PM, Barrett JS, Nathan DM, Shepherd SJ, Gibson PR. Reduction of dietary poorly absorbed short-chain carbohydrates (FODMAPs) improves abdominal symptoms in patients with inflammatory bowel disease-a pilot study. J Crohns Colitis 2009; 3: 8-14 [PMID: 21172242 DOI: 10.1016/j.crohns.2008.09.004]

124. Barrett JS, Gearry RB, Muir JG, Irving PM, Rose R, Rosella O, Haines ML, Shepherd SJ, Gibson PR. Dietary poorly absorbed, short-chain carbohydrates increase delivery of water and fermentable substrates to the proximal colon. Aliment Pharmacol Ther 2010; 31: 874-
882 [PMID: 20102355 DOI: 10.1111/j.13652036.2010.04237.x]

125. Shepherd SJ, Parker FC, Muir JG, Gibson PR. Dietary triggers of abdominal symptoms in patients with irritable bowel syndrome: randomized placebo-controlled evidence. Clin Gastroenterol Hepatol 2008; 6: 765-771 [PMID: 18456565 DOI: 10.1016/j.cgh.2008.02.058]

126. Pedersen N, Ankersen DV, Felding $M$, Wachmann H, Vegh Z, Molzen L, Burisch J, Andersen JR, Munkholm P. Low-FODMAP diet reduces irritable bowel symptoms in patients with inflammatory bowel disease. World J Gastroenterol 2017; 23: 3356-3366 [PMID: 28566897 DOI: 10.3748/wjg.v23.i18.3356]

127. Ghouri YA, Richards DM, Rahimi EF, Krill JT, Jelinek KA, DuPont AW. Systematic review of randomized controlled trials of probiotics, prebiotics, and synbiotics in inflammatory bowel disease. Clin Exp Gastroenterol 2014; 7: 473487 [PMID: 25525379 DOI: 10.2147/ceg.s27530]

128. Mitsuyama K, Saiki T, Kanauchi O, Iwanaga T, Tomiyasu N, Nishiyama T, Tateishi H, Shirachi A, Ide M, Suzuki A, Noguchi K, Ikeda H, Toyonaga A, Sata M. Treatment of ulcerative colitis with germinated barley foodstuff feeding: a pilot study. Aliment Pharmacol Ther 1998; 12: 12251230 [PMID: 9882030]

129. Heaton KW, Thornton JR, Emmett PM. Treatment of Crohn's disease with an unrefinedcarbohydrate, fibre-rich diet. Br Med J 1979; 2: 764-766 [PMID: 519185]

130. Ananthakrishnan AN, Khalili $H$, Konijeti GG, Higuchi LM, de Silva P, Korzenik JR, Fuchs CS, Willett WC, Richter JM, Chan AT. A prospective OJGH: https://escipub.com/open-journal-of-gastroenterology-and-hepatology/ 
Yoshihiro Yokoyama et al., OJGH, 2019 2:20

study of long-term intake of dietary fiber and risk

of Crohn's disease and ulcerative colitis. Gastroenterology 2013; 145: $\quad$ 970-977

[PMID: $23912083 \quad$ DOI:

10.1053/j.gastro.2013.07.050]

131. Levenstein S, Prantera C, Luzi C, D'Ubaldi A. Low residue or normal diet in Crohn's disease: a prospective controlled study in Italian patients. Gut 1985; 26: 989-993 [PMID: 2996991]

132. Curro D, laniro G, Pecere S, Bibbo S, Cammarota G. Probiotics, fibre and herbal medicinal products for functional and inflammatory bowel disorders. $\mathrm{Br} \quad \mathrm{J}$ Pharmacol 2017; 174: 1426-1449 [PMID: 27696378 DOI: 10.1111/bph.13632]

133. Srutkova D, Schwarzer M, Hudcovic T, Zakostelska Z, Drab V, Spanova A, Rittich B, Kozakova H, Schabussova I. Bifidobacterium longum CCM 7952 Promotes Epithelial Barrier Function and Prevents Acute DSS-Induced Colitis in Strictly Strain-Specific Manner. PLoS One 2015; 10: e0134050 [PMID: 26218526 DOI: 10.1371/journal.pone.0134050]

134. Ganji-Arjenaki M, Rafieian-Kopaei M. Probiotics are a good choice in remission of inflammatory bowel diseases: A meta-analysis and systematic review. J Cell Physiol 2018; 233: 2091-2103 [PMID: 28294322 DOI: 10.1002/jcp.25911]

135. Derwa Y, Gracie DJ, Hamlin PJ, Ford AC. Systematic review with meta-analysis: the efficacy of probiotics in inflammatory bowel disease. Aliment Pharmacol Ther 2017; 46: 389400 [PMID: 28653751 DOI: 10.1111/apt.14203]
136. Tursi A, Brandimarte G, Papa A, Giglio A, Elisei W, Giorgetti GM, Forti G, Morini S, Hassan C, Pistoia MA, Modeo ME, Rodino S, D'Amico T, Sebkova L, Sacca N, Di Guilio E, Luzza F, Imeneo M, Larussa T, Di Rosa S, Annese V, Danase S, Gasbarrini A. Treatment of relapsing mild-to-moderate ulcerative colitis with the probiotic VSL\#3 as adjunctive to a standard pharmaceutical treatment: a double-blind, randomized, placebo-controlled study. Am J Gastroenterol 2010; 105: 2218-2227 [PMID: 20517305 DOI: 10.1038/ajg.2010.218]

137. Takeda Y, Nakase H, Namba K, Inoue S, Ueno S, Uza N, Chiba, T. Upregulation of T-bet and tight junction molecules by Bifidobactrium longum improves colonic inflammation of ulcerative colitis. Inflamm Bowel Dis 2009; 15: 1617-1618 [PMID: 19161180 DOI: 10.1002/ibd.20861]

138. Tamaki H, Nakase $H$, Inoue $S$, Kawanami C, Itani T, Ohana M, Kusaka T, Uose S, Hisatsune H, Tojo M, Noda T, Arasawa S, Izuta M, Kubo A, Ogawa C, Matsunaka T, Shibatouge M. Efficacy of probiotic treatment with Bifidobacterium longum 536 for induction of remission in active ulcerative colitis: A randomized, double-blinded, placebocontrolled multicenter trial. Dig Endosc 2016; 28: 67-74 [PMID: $26418574 \quad$ DOI: 10.1111/den.12553]

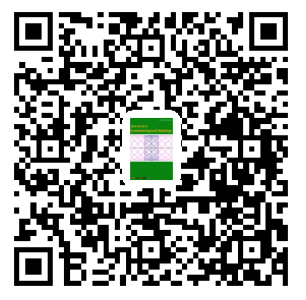

